Discussion Paper No. 960

\title{
IS BEING AGREEABLE A KEY TO SUCCESS OR FAILURE IN THE LABOR MARKET?
}

\author{
Sun Youn Lee \\ Fumio Ohtake
}

February 2016

The Institute of Social and Economic Research

Osaka University

6-1 Mihogaoka, Ibaraki, Osaka 567-0047, Japan 


\title{
Is Being Agreeable a Key to Success or Failure in the Labor Market? ${ }^{\dagger}$
}

\author{
SunYoun Lee ${ }^{1}$, Fumio Ohtake $^{2}$
}

The aim of this study was to elucidate how individual differences in noncognitive skills, as measured by the Big Five personality traits, explain variation in labor market outcomes. Japanese and U.S. survey data were analyzed to examine the associations between personality traits and later outcomes in the two countries. We focused on country-specific, noncognitive determinants of annual income, which were found in agreeableness among male workers. Agreeableness seemed to contribute to annual income in Japanese men, whereas it acted as a penalty in American men. In both countries, higher agreeableness tended to translate into higher income for those working at large companies (1,000 employees or more) compared with those working at small companies. Although agreeableness was rewarded by income, it did not necessarily lead to career advancement. Furthermore, the agreeableness premium was still observed even after controlling for labor-related variables such as occupational choice and working hours. This suggests that agreeableness might act as part of a skill set that directly improves job performance and productivity at large companies, rather than acting indirectly through career advancement or occupational choice.

Keywords: Big Five personality, agreeableness, company size, income, career advancement JEL Classification Number: J01, D03, J24

\footnotetext{
${ }^{\dagger}$ This study was supported by a Grant-in-Aid for Scientific Research A (Grant No. 26245041) from the Japan Society for the Promotion of Science, and the Joint Usage/Research Center at ISER/Osaka University. We are grateful to seminar participants at the Research Institute of Economy, Trade and Industry (RIETI), and the 8th Trans-Pacific Labor Seminar (TPLS) for their constructive comments. This paper is based on preliminary results published in the RIETI Discussion Papers Series 14-E-023. However, our main hypotheses and ensuing empirical framework were newly set up and tested. The authors are responsible for any errors in this article.

${ }^{1}$ Faculty of International Studies, Meiji Gakuin University, E-mail: sylee@k.meijigakuin.ac.jp

${ }^{2}$ Institute of Social and Economic Research, Osaka University, E-mail: ohtake@iser.osaka-u.ac.jp
} 


\section{Introduction}

Dee and West (2008) and Heckman, Moon, Pinto, Savelyev, and Yavitz (2010) have shown the importance of fostering students' noncognitive skills through school programs and governmental policies. Findings of these studies indicate that noncognitive skills have greater long-term effects on life outcome than do cognitive skills. Chetty, Friedman, Hilger, Saez, Schanzenbach, and Yagan (2011) reported persistent impacts of Project STAR, a Tennessee class-size reduction demonstration project, on later outcomes through the development of students' noncognitive skills, in contrast to the fade-out effect of class quality on test scores after the completion of the project. Thus, early intervention by formulating and financing school programs or government policies to foster noncognitive skills is as important as, or even more important than, helping children achieve their educational potential. This is particularly relevant to those raised in low-income families, as such initiatives help prevent a vicious cycle of intergenerational inequality.

In economics, little attention has been paid to the relation between noncognitive skills and educational and career success. It is widely recognized, both in practice and in research, that measured cognitive ability is a strong predictor of educational outcomes and career success, but the role of noncognitive skills has received less attention in explaining life outcomes. Heckman (1999) argued that serious bias can arise when accumulated human capital is evaluated without consideration of both cognitive skills, as measured by test scores or IQ index, and noncognitive skills, such as motivation and social adaptability. Some evidence suggests that approximately $20-30 \%$ of individual earnings (in standard earning equations) can be explained by years of schooling and work experience in addition to demographic variables, including family socioeconomic status (Bowles, Gintis, \& Osborne, 2001). This implies that much of the variation in labor market success remains unexplained.

Several studies have recently focused on noncognitive skills as a key predictor of educational attainment (Borghans, Meijers, \& ter Weel, 2006; Heckman, Stixrud, \& Urzua, 2006) and earnings (Heineck \& Anger, 2010; Carneiro, Crawford, \& Goodman, 2007; Muller \& Plug, 2006). Heckman et al. (2006) have found that improvements in personality traits, self-control, and self-esteem in particular, from the 25th to the 75th percentile of its distribution, while holding the level of cognitive skills constant, increase the probability of being a four-year college graduate at age 30 by approximately 25 percentage points. The Big Five personality traits conscientiousness and openness to experiences have been identified as the best personality predictors of educational performance and years of education, respectively (Borghans et al., 2006). Some studies have examined the importance of noncognitive skills in labor market outcomes. For example, Heckman, Hsee, and Rubinstein (2001) found that, after controlling for measured ability, those who obtained a GED (General Educational Development) high school certification 
in the United States tend to earn less than high school dropouts do. The authors explained that a lack of noncognitive skills such as discipline, patience, and motivation accounted for the lower earnings among GED holders compared with dropouts with the same ability.

Noncognitive skills explain variation in schooling and labor market outcomes that is left unexplained by cognitive skills. Analysis of noncognitive skills is also important in a policy context. Some school programs and government policies have shown the long-term effects of noncognitive skill development. Heckman and Kautz (2012) emphasized the significant effect of several public policies that enhance soft skills on children's educational outcomes. For example, the Perry Preschool Program for disadvantaged young children demonstrated the effects of noncognitive skill development on long-term life outcomes. Chetty et al. (2011) found that noncognitive skills, fostered by changes in school system, have a greater long-term effect on later outcomes than cognitive skills do. Almlund, Duckworth, Heckman, and Kautz (2011) emphasized that compared with cognitive ability, noncognitive skills are responsive to parental behaviors, allowing substantial room for parental investments in education and for policy interventions.

As a measure of noncognitive skills, the Five Factor Model (hereinafter, the "Big Five personality traits”) is a broadly accepted model of personality in the psychology and economics literature. For a brief measure of Big Five personality traits, many recent studies have utilized a 5- or 10-item inventory calculated on bipolar scales for five personality facets: extroversion, agreeableness, conscientiousness, emotional stability, and openness to experiences. Gosling, Rentfrow, and Swann (2003) examined these inventories in terms of (a) their validity, using self-, observer, and peer ratings; (b) the pattern of external correlates, using self-ratings on other measures; and (c) test-retest reliability, using a second assessment of the same participants. Gosling et al. (2003) concluded that 5- and 10-item inventories were reasonable proxies for lengthier Big Five instruments. Several previous studies have attempted to elucidate how personality traits act as predictors of educational and labor market outcomes. The stability of personality traits is a subject of controversy. Although some studies have noted changes in personality traits over an individual's life course with changes in environment or gene expression (Roberts \& Jackson, 2008), it is widely accepted that personality traits tend to be stable in adulthood. In a review of the stability of personality traits and their predictive power, Almlund et al. (2011) noted that personality development tends to stabilize around the age of 30 years (Caspi, 1997; Soldz \& Vaillant, 1999). Cobb-Clark and Schurer (2012) concluded that personality traits in working-age adults are stable over a 4-year period, based on their findings of small changes in average personality during the given periods and little relation between intra-individual personality characteristics and life events (e.g., adverse employment, health, or family events). 
The main motivation for utilizing personality traits is that a single measure cannot predict much of the variance in educational and labor market outcomes. Also, these soft skills can explain variance in outcomes that are not attributable to effects of cognitive skills. According to Borghans, Golsteyn, Heckman, and Humphries (2011), personality traits are incrementally valid in explaining variance in educational outcomes measured by achievement tests and grades, after deconstructing the outcomes into IQ and personality traits. Using German data, Almlund et al. (2011) explained that consciousness, long considered the best predictor of later-life labor outcomes, has more explanatory power than intelligence.

In this study, we aimed to determine the predictive power of personality traits and to explain the mechanisms underlying the relations between personality traits and later outcomes by considering country differences. Our primary focus was the extent to which noncognitive skills, as measured by the Big Five personality traits, explain variations in educational and labor market outcomes after controlling for socioeconomic variables. This study differs from the prior research in this field in several ways. First, country differences are difficult to examine because previous studies used different measures of personality traits. Therefore, we utilized survey data from Japan and the United States, which we collated using the same questions during the same year. Second, because many studies reported only simple correlations or simple standardized regression coefficients, such estimated relations could not control for other factors that might influence educational and labor market outcomes. Therefore, we utilized the same variables and ran multiple regressions while controlling for other factors that might affect outcomes, including cognitive ability and other socioeconomic variables. Finally, we focused on some interesting country differences in personality traits affecting men's income, as found in agreeableness. Because this particular personality trait suggests the existence of country-specific noncognitive determinants of later outcomes, we analyzed its association with men's income and career advancement in Japan and America. We also examined the predictive power of personality traits on educational attainment, income, and career advancement in order to determine the channels through which personality traits affect labor market outcomes. More specifically, we analyzed the mechanisms behind the relations between personality traits and later outcomes by firm-size and occupation status. Some personality traits might directly affect income by improving an individual's job performance and productivity or indirectly affect labor market outcomes through occupational choice and career advancement.

The remainder of the paper is organized as follows. Section 2 reviews prior studies related to this work. Section 3 discusses the dataset and explains how the variables were constructed for subsequent analyses. Section 4 presents the estimation results. Finally, Section 5 discusses implications of the findings and concludes the paper. 


\section{Research Background ${ }^{3}$}

\subsection{Big Five Personality Traits}

The Big Five personality traits are a unifying framework comprising five basic characteristics: extroversion, agreeableness, conscientiousness, emotional stability, and openness to experiences. More specifically, these five characteristics are: extroverted, enthusiastic (sociable, assertive, talkative, active, unreserved, not shy); agreeable, kind (trusting, generous, sympathetic, cooperative, not aggressive, not cold); dependable, organized (hard-working, responsible, self-disciplined, thorough, not careless, not impulsive); emotionally stable, calm (relaxed; self-confident; not any of anxious, moody, easily upset, or easily stressed); open to experience, imaginative (curious, reflective, creative, deep, open-minded, unconventional) (Gosling et al., 2003). Ten questions measuring these five personality traits ${ }^{4}$ are each rated on a 7-point scale, ranging from 1 (strongly disagree) to 7 (strongly agree). The average of the two bipolar items that make up each scale is then calculated and used in subsequent analyses. For example, if a respondent scores 5 on item 1 (extroverted, enthusiastic) and 2 on item 6 (reserved, quiet), the complement of the score for item 6 is found by replacing the 2 with a 6 . Then, the average of the score for item 1 and the (complementary) score for item 6 is calculated.

These single-item scales are typically psychometrically inferior to multiple-item scales, but Burisch (1997) and Gosling et al. (2003) showed that short and simple depression scales can be just as valid as long and sophisticated ones. In addition, Epstein (1979) emphasized the view that, when averaged over tasks and situations at a point in time, people exhibit a predictable pattern of average behavior ("measured personality”) with a high degree of reliability across situations. These previous studies support the validity of the Big Five personality traits as a measure of noncognitive skills that affect educational and labor market outcomes. As explained in the Introduction, stability of personality traits is controversial, thus, calling into question the legitimacy of adopting this premise when analyzing personality traits in relation to school and later-life labor outcomes. However, some authors have argued that personality development tends to stabilize from the age of 30 years onward (Caspi, 1997; Soldz \& Vaillant, 1999). Cobb-Clark and Schurer (2012) also found that personality traits at working age were stable over a 4-year period and did not vary significantly under any life events. Along these lines, in this paper, we treat personality as invariant over an individual's lifetime.

\footnotetext{
${ }^{3}$ Sections 2.1 to 2.3 summarize Lee and Ohtake (2014). Please refer to this paper for more details.

${ }^{4}$ In the present study, the Big Five personality traits are measured based on responses to the self-report questionnaire.
} 


\subsection{Personality Traits and Educational Outcomes}

Although much of the variation in labor-market success remains unexplained (Bowles et al., 2001), prior research has observed the role of personality traits in explaining later-life outcomes and investigated the mechanisms behind these associations. However, it should be noted that results for the association between personality traits and later outcomes vary by survey data and analysis method, and that simple regression or correlation, rather than a causal relation, is still the basis for many findings.

Many studies have investigated the extent to which noncognitive skills explain individual variation in educational outcomes (e.g., test scores, grade point average [GPA], and total years of schooling). Two of the Big Five traits-conscientiousness and openness to experiences-were found to be particularly important indicators of the total years of education that individuals complete in their lifetimes. In addition, emotional stability, as measured by locus of control and self-esteem, was reported to be an important indicator of adolescent schooling decisions (Almlund et al., 2011).

Conscientiousness is considered the most predictive Big Five trait across many outcomes (Hampson, Goldberg, Vogt, \& Dubanoski, 2007; Roberts, Kuncel, Shiner, Caspi, \& Goldberg, 2007; Poropat, 2009), and is the trait most consistently linked to academic success (O’Connor \& Paunonen, 2007). In a representative sample of Germans aged 21 to 94 years, Almlund et al. (2011) found that variation in years of schooling is best explained by the degree of conscientiousness, even after controlling for intelligence. These authors found it particularly noteworthy that this trait had more explanatory power than intelligence, and that the trait's predictive power was stronger among men than among women. Given that conscientiousness is often associated with motivation, the positive correlation between conscientiousness and educational attainment might suggest that more motivated students perform better than less motivated counterparts.

Many previous studies on the role of openness to experiences as a predictor of academic performance have reported a positive relation between this trait and both GPA and final course grades (Lievens, Dilchert, \& Ones, 2009; Lounsbury, Sundstrom, Loveland, \& Gibson, 2003). The mechanisms behind this positive relation are often explained by the positive correlation between openness to experiences and measures of intelligence (Chamorro-Premuzic \& Furnham, 2005). Also, Ackerman and Heggestad (1997) stated that openness to experiences is the only Big Five factor moderately associated with general intelligence ( $r=0.33$, as measured in a meta-analysis). Intelligence is a strong predictor of educational outcomes, so it is easy to appreciate why openness to experiences has a positive effect on educational attainment.

Emotional stability is also expected to be an important factor for educational attainment. Heckman et al. (2006) found that emotional stability increased the probability of graduating from high school for boys 
in the lowest quantiles of the personality distribution. Emotional stability (low neuroticism), which is linked to locus of control and self-esteem, seems to play an important role in adolescent educational decisions. In addition, this trait has been often interpreted in relation to "stress reaction" or "debilitating anxiety" (Chamorro-Premuzic \& Furnham, 2005). Moreover, in studies that used representative samples of U.S. (Goldberg, Sweeney, Merenda, \& Hughes, 1998), Dutch (van Eijck \& de Graaf, 2004), and German (Almlund et al., 2011) individuals, emotional stability was found to be positively correlated with educational attainment. Furthermore, several studies have found a significant positive relation between locus of control (as a measure of emotional stability) and high school graduation (Barón \& Cobb-Clark, 2010; Cebi, 2007; Coleman \& DeLeire, 2003).

In contrast, extroversion and agreeableness are not consistently associated with academic performance (O’Connor \& Paunonen, 2007). According to some conflicting findings, extroverted children tend to perform better at school until the age of 12 years (Goff \& Ackerman, 1992), whereas introverted students achieve higher grades (Yates, Yates, \& Lippett, 1995). Some recent studies have reported a positive effect of agreeableness on educational outcomes, such as GPA (Farsides \& Woodfield, 2003; Gray \& Watson, 2002) and final course grades (Conard, 2006), whereas other studies have found either no significant correlation or a significant but negative correlation between agreeableness and educational attainment (Goldberg et al., 1998; van Eijck \& de Graaf, 2004).

\subsection{Personality Traits and Labor Market Outcomes}

The predictive power of personality traits varies across type of labor market outcome. However, it is widely accepted that conscientiousness is the best predictor of economic success, whereas emotional stability (resp., high neuroticism) is often positively (resp., negatively) associated with labor market outcome. Conscientiousness is associated with being well organized, hard-working, and achievement-oriented, and best predicts overall job performance and wages across occupational categories, whereas the predictive power of intelligence declines as jobs become more complex (Almlund et al., 2011). In particular, men with a high degree of conscientiousness seem to earn higher wages and are more likely to be promoted than other men (Judge, Higgins, Thoresen, \& Barrick, 1999). In addition, because emotional stability affects job search efforts (Almlund et al., 2011), emotionally stable individuals are more motivated to find a job that fits their abilities and skills. Semykina and Linz (2007) examined the importance of emotional stability using Russian data, and found that variation in personality traits, as measured by locus of control, accounted for $8 \%$ of the gender wage gap.

Some recent studies have observed a relation between the two traits of conscientiousness and emotional stability and labor market outcomes. Using U.S. data, Duckworth and Weir (2010) reported that 
conscientious and emotionally stable adults attained higher lifetime income. More specifically, they found that an increase of one standard deviation on conscientiousness and emotional stability was associated with, respectively, a 9\% and 5\% increase in lifetime income. Similarly, Judge et al. (1999) found that, controlling for childhood IQ, the strongest predictor of a composite measure of self-reported income and occupational status was childhood conscientiousness, with an effect size higher than that of childhood IQ. According to Uysal and Pohlmeier (2011), conscientiousness and emotional stability were associated with unemployment duration, which suggests that personality traits in workers can influence job-search intensity.

In addition to conscientiousness and emotional stability, Fletcher (2013) highlighted the importance of extroversion as a predictor of economic success, using a national sample of siblings and twins. He noted that it is important to consider individual-level heterogeneity in unobserved generic ability for both cognitive and non-cognitive skills. Previous heritability studies have indicated that measures of personality traits tend to be about $40-60 \%$ heritable, suggesting a significant genetic component to human behavior (Bouchard \& Loehlin, 2001). The results indicating a strong association between extroversion and income were obtained after controlling for individual differences related to family background, occupational sorting, and educational attainment.

\subsection{Expected Findings of the Present Study}

According to Judge et al. (1999), studies on organizational psychology agree that conscientiousness, extroversion, and emotional stability are the Big Five factors most strongly correlated with career success. This consensus is also seen in previous empirical research on noncognitive skills, as discussed in Section 2.3. Although our estimation results were consistent overall with previous studies, we found a difference in agreeableness between Japan and the United States in relation to labor market outcomes, which is the focus of the present paper. Agreeableness is defined as a "tendency to act in a cooperative and unselfish manner” (John \& Srivastava, 1999). Being more cooperative and likeable could benefit employees with these characteristics in teamwork settings. However, the negative side of being agreeable is that “extremely agreeable individuals may sacrifice their success in pleasing others” (Judge et al., 1999, p. $625)$.

Many empirical studies have found no significant correlation between agreeableness and labor market outcomes, and even when a correlation was significant, the effect was likely to be negative. We hypothesized that agreeableness can be rewarded in a teamwork environment (measured by the number of employees) and that the reward can differ by employment status (between ordinary employees and managers). To examine the effect of company size and employment status, we restricted our sample to 
employees working for private companies. The income effect of agreeableness could be either direct or indirect (Heckman et al., 2006; Borghans et al., 2008). This personality trait is part of a skillset, such as educational attainment and job training, that directly improves productivity. In other words, agreeableness could lead directly to higher income by improving an individual's job performance. In contrast, agreeableness could indirectly affect labor market outcomes through occupational choice and career advancement. To distinguish between these two effects, we formulated empirical models to assess the extent to which coefficients of personality traits change in relation to inclusion of labor-related variables (e.g., occupation, employment status, and working hours). Therefore, finding no significant change in agreeableness, even with occupational choice, career advancement, and working hours held constant, would suggest that a direct effect on productivity leads to higher earnings.

\section{Data and Empirical Framework}

This study is based on survey data obtained from the "Preference and Life Satisfaction Survey" by the Center of Excellence project of Osaka University. The data come from two questionnaire surveys conducted in Japan and the United States. This survey was first conducted in Japan by the drop-off and pick-up method in February 2003, using a random sample drawn from 6,000 individuals selected by a double-stratified, random-sampling method. It has been conducted annually since then, and new samples were added in the 2004, 2006, and 2009 surveys by the drop-off method. In the United States, a panel survey, which began in January and February of 2005 by a mailing method, included 12,338 individuals and has since been conducted yearly. New samples were added in the 2007, 2008, and 2009 surveys. We primarily used 2012 survey data for our analyses of both the Japanese and the U.S. data. In this study, personality traits and labor market outcomes were based on survey year 2012, whereas total years of schooling and some of the individual characteristics were taken from the 2011 and 2010 surveys conducted in both countries.

Table 1 shows mean values of each personality trait. The Japanese respondents had a comparatively high degree of agreeableness, whereas Americans scored higher on conscientiousness (see Figure 2 for country comparisons). Similarly, differences in personality traits by gender indicate that women were more agreeable and extroverted, whereas men were more emotionally stable and open to new experiences (Table 1). Some of these trends are consistent with findings of previous studies of gender differences in personality, which have indicated that women typically have a lower degree of emotional stability and openness to experiences (Feingold, 1994; Costa, Terracciano, \& McCrae, 2001).

Using the minimum number of years required to attain each educational level, we obtained the values of 13.39 for Japanese and 14.43 for Americans as the mean number of years of schooling. In addition to 
using a continuous measure for educational attainment (years of schooling), we also examined the transition to tertiary education. In our samples, $27 \%$ of Japanese respondents and 39\% of American respondents completed college, and $2 \%$ of Japanese respondents and 13\% of American respondents continued on to graduate school, across all age groups ${ }^{5}$. In addition, $17 \%$ of the Japanese and American respondents indicated promotion to a management position at a private company. In the U.S. sample, $14 \%$ of women were in a management position, whereas in Japan, female managers accounted for only $4 \%$ of the female labor force ${ }^{6}$. The percentage of male employees working for private companies with 1,000 employees or more was $21 \%$ in Japan and $31 \%$ in the United States ${ }^{7}$.

\subsection{Estimation Methods: Schooling}

We also investigated personality trait effects on a wide range of later life outcomes. Because personality stabilizes around the age of 30 years (Caspi, 1997; Soldz \& Vaillant, 1999), we restricted our sample to individuals aged 30 to 65 years for all estimations. The base model for examining educational outcomes is defined as follows:

$$
\text { Schooling }_{i}=\beta_{10}+\beta_{11} \text { Big }_{i}+X_{i} \beta_{12}+u_{i 1}
$$

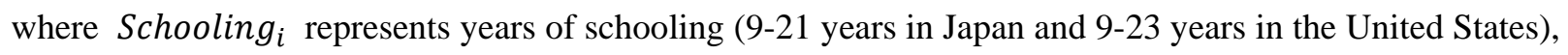
and $B i g 5_{i}$ indicates continuous variables of the Big Five personality traits. $X_{\mathrm{i}}$ is a vector of individual characteristics that are assumed to affect later outcomes: age, age squared, gender, and years of schooling (parental educational attainment is controlled for in the analysis of educational attainment). For the U.S., because some studies have pointed out differences in later outcomes between races (Fletcher, 2013), $X_{\mathrm{i}}$ includes race dummies. To investigate effects of personality traits on the probability of attaining a higher educational level, educational attainment was added to the base model as a binary variable that takes a

\footnotetext{
${ }^{5}$ According to the data of Ministry of Education, Culture, Sports, Science and Technology, 25\% of Japanese people completed college between 1965 to 2000 (four-year university) (http://www.mukogawa-u.ac.jp/ kyoken/data/13.pdf ). According to U.S. census data, 31\% of Americans have a bachelor's degree or higher, and $11 \%$ of college graduates continued to graduate school in 2012 (https://www.census.gov/hhes/socdemo/education/data/cps/2012/tables.html).
}

${ }^{6}$ The Japanese government reported that $6.5 \%$ of women working in private companies held management positions (section chief or higher) in 2009. (http://www.gender.go.jp/kaigi/renkei/2020_30/pdf/2020_30_all.pdf). In 2013, women in the United States were $14.6 \%$ of executive officers, $8.1 \%$ of top earners, $4.6 \%$ of Fortune 500 CEOs, and held $16.9 \%$ of Fortune 500 board seats (http://www.catalyst.org/knowledge/statistical-overview-women-workplace).

${ }^{7}$ According to data of the Ministry of Health, Labour and Welfare, 22.4\% of Japanese employees worked for companies with 1,000 employees or more in 2012 (http://www.mhlw.go.jp/toukei/youran/roudou-nenpou/02.html). In the U.S., the Bureau of Labor Statistics reported that 38.87\% of Americans worked for companies with 1,000 employees or more in 2012 (http://www.bls.gov/web/cewbd/table_f.txt). 
value of 1 if the respondent completed college education (or at least a master's degree program) and 0 otherwise. We carried out all estimations separately for men and women to look for any gender differences in addition to country differences.

\subsection{Estimation Methods: Labor Market Outcomes}

Model 2 is used to examine the effects of personality traits on income:

$$
\ln \text { Income }_{i}=\beta_{20}+\beta_{21} \text { Big }_{i}+X_{i} \beta_{22}+Z_{i} \beta_{23}+u_{i 2},
$$

where $\ln$ Income $_{i}$ is the natural logarithm of individual annual income, and $X_{\mathrm{i}}$ is a vector of individual characteristics, the same as in Model 1. $Z_{i}$ is a vector of labor-related variables that are assumed to affect annual income: type of occupation, type of employment, company size, years of employment at current workplace, and weekly working hours. In Equation (2), to investigate the mechanism behind the effect of personality traits on income, we added years of education and labor-related variables separately into the model (see Table 3). The rest of the estimations were carried out using the sample of only men, considering that women's decisions on whether to work or not could introduce selection bias.

We examined differences in personality trait effects between employees of large and small companies by further restricting our sample to those working for private companies. We included an interaction term for each of the Big Five personality traits in combination with a company size dummy that takes a value of 1 if the company has 1,000 or more employees and 0 otherwise (Table 4). In addition, we added similar interaction terms between the Big Five personality traits and a management position dummy (managers $=1$ ) to Equation (2) of the basic model of earnings. See Table 5 (columns 1 and 2) for estimation results. To investigate differences in the effects of personality traits, in particular agreeableness, in relation to company size and employment status, we included interaction terms of these three variables into Model 2 (Table 5, columns 3 and 4): agreeableness, a company size dummy and a management position dummy.

To examine the effects of personality traits on career advancement, model 3 is set up as follows:

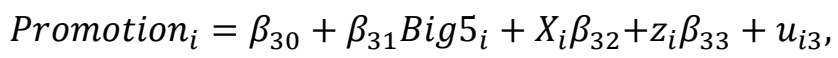

where Promotion $_{i}$ represents a binary variable that equals one if the respondent was in a management position at the time of the survey and zero otherwise ${ }^{8}$, and $X_{\mathrm{i}}$ is a vector of individual characteristics, as in Model $1 . z_{i}$ is a vector of labor-related variables that are assumed to affect an individual's career

\footnotetext{
8 The Japanese survey included those in a management position, company executives, or board members.
} 
advancement (i.e., company size, type of employment, working hours, and years of employment at current workplace).

\subsection{Estimation Methods: Other Labor Outcomes}

To examine the effects of personality traits on other later outcomes aside from economic rewards, we set up Model 4, the last model, as follows:

$$
\text { Happiness }_{i}=\beta_{40}+\beta_{41} \text { Big }_{i}+\beta_{42} \text { INCOME }_{i}+X_{i} \beta_{43}+Z_{i} \beta_{44}+u_{i 4} \text {, }
$$

Here Happiness $s_{i}$ represents degree of happiness as measured on an 11-point scale by the following questions: “Overall, how happy would you say you are currently? Using a scale from 0 to 10 where ' 10 ' is 'very happy' and ' 0 ' is 'very unhappy,' how would you rate your current level of happiness?” $X_{i}$ is a vector of individual characteristics, as in Model 1 , and $Z_{i}$ represents the same variables used in Model 2. Model 4 is the same as Model 2 except for the dependent variables. To compare the effects of personality traits and other individual labor-related variables on degree of happiness using results of Model 2, we set up the same model. Furthermore, we examined how the effects of personality traits $\left(\beta_{41}\right)$ change when annual income (INCOME $E_{i}$ ), the dependent variable of Model 2, is held constant, and we investigated the partial effect of annual income $\left(\beta_{42}\right)$ on degree of happiness by using Model 4.

\section{Estimation Results}

\subsection{Effects of Personality Traits on Educational Attainment}

Table 2 presents results of the relation between noncognitive skills and years of schooling cosmpleted. The two left columns in the upper and bottom panels show estimation results for years of schooling in Japan and the United States, respectively. Regressions were run with and without adjustment for years of schooling attained by respondents' parents. Parents' completed years of schooling can serve as a proxy for genetic inheritance of cognitive ability, socioeconomic status, and/or personality traits. Children of highly educated parents tend to become highly educated partly because of the intergenerational inheritance of unobserved abilities, which positively affect children's educational decisions. Our overall results indicate that parental background mitigates the effects of the personality traits, although the statistical significance of personality traits changed very little even when controlling for parental effect.

In Japan, among the different facets of personality traits, agreeableness seemed to have a positive effect on total years of schooling among men. Agreeableness was also a statistically significant factor both with and without control of parental educational background. In contrast, conscientiousness was statistically significant among only American respondents. As shown by the descriptive statistics in Table 
1, agreeableness (resp., conscientiousness) has the highest mean values among the five personality traits in Japan (resp., in the United States). Even after controlling for socioeconomic variables, the effect of these traits on educational attainment was statistically significant in both countries. In this paper, we focused on country differences in agreeableness. We found that although agreeableness had a positive effect on schooling in Japan, it had a negative effect in the United States, and was a significant negative factor among women in the United States. Aside from agreeableness and conscientiousness, the degrees of openness to experiences and emotional stability were important for schooling in Japan and the United States. Implications of the effects of these two personality traits can be explained by their relation to degree of intelligence, interest in learning, and self-control, all of which significantly affect cognitive ability and adolescent schooling decisions (see Section 2.2 for details).

Figure 1 displays standardized regression coefficients of personality traits associated with years of schooling, after controlling for the basic demographic characteristics: age, age-squared, and gender as well as race dummies for American samples. The two rectangular bars represent estimates of standardized regression coefficients and the line bars represent robust standard errors, with darker rectangular bars representing estimates obtained after controlling for parental background. After controlling for parents' educational attainment, a one standard deviation increase in agreeableness and conscientiousness was associated with a 0.115 and 0.215 standard deviation increase, respectively, in total years of schooling completed in Japan and the United States. This is approximately equivalent to an increase in schooling by 0.23 and 0.52 years in Japan and the United States, respectively. Compared to the effect of personality traits, the effect of parental educational background was substantial in both countries, highlighting the importance of parental socioeconomic status and generic inheritance of cognitive and noncognitive skills. The inclusion of parental background decreased the size of standardized regression coefficients of personality traits by approximately 0.01. However, agreeableness and conscientiousness were still significantly correlated with educational attainment even after controlling for parental background.

Figure 1 presents a simple comparison with previous studies that have reported standardized regression coefficients of personality traits. Results based on American respondents in our study were consistent with results reported by Goldberg et al. (1998), which were based on a representative sample of U.S. working adults, aged 18 to 75 years. Goldberg and colleagues found significant negative correlations between academic success and agreeableness and extroversion, as well as significant positive correlations for conscientiousness and openness to experiences.

In addition to total years of schooling completed, Table 2 (columns 3 and 4) shows the effect of personality traits on the probability of transition to higher levels of education (i.e., college and graduate school). Japanese males students who were more agreeable and conscientious were also more likely to go 
to college. In contrast, introversion and openness to experiences positively affected the decision of Japanese men to enter graduate school. In contrast, we found no statistically significant personality effect on female students' decision to transition from high school to college, whereas extroversion acts as a determinant for Japanese women's decision to enter graduate school. Our results suggest that, in Japan, the effects of personality traits vary at different educational transition points. Interestingly, agreeableness, which is the best predictor for educational attainment below the college level, became negatively associated with graduate-level educational attainment, although this effect was not statistically significant. In the United States, we observed no apparent significant difference in the effects of personality traits on educational transition when compared with results obtained using the continuous variable of total years of schooling. More specifically, conscientiousness and emotional stability seemed to play an important role in the decision to pursue higher levels of education, as well as final educational attainment.

\subsection{Effects of Personality Traits on Income}

In this section, the relation between annual income and personality factors is investigated (Table 3). We summarized all estimations by gender and country. Table 3 (upper panel) describes results of Japanese male and female workers. Differences (see columns 1 through 3) depended on inclusion of variables of educational attainment (type of occupation, years of schooling, type of employment) and labor (working hours, company size). As for Japanese male workers, column 3 shows that extroversion, agreeableness, conscientiousness are seemingly important factors affecting annual income. In Japanese female workers, extroversion appears to correlate more consistently with income. American male workers were rewarded by non-agreeableness and conscientiousness, everything else being equal. In American female workers, extroversion, non-agreeableness, and emotional stability seemed to correlate with annual income. These results occurred when type of occupation, type of employment, years of schooling, and working hours were held constant. Even when education attainment and labor market variables were held constant, personality traits were still significantly associated with income, which suggests that they might act as an individual's set of productive traits, such as educational attainment. In other words, these noncognitive skills have a rather direct effect on productivity, which is reflected by income.

Column 4 presents results based on a restricted sample of those working at private companies. For this estimation, we used the restricted sample of private companies to analyze how the effect of agreeableness on men's income differs by company size and employment status. Column 4 presents observed country differences in agreeableness. In Japan, agreeableness had a statistically significant positive effect on annual income as well as years of schooling among men, whereas it had a negative 
correlation with income in the United States. This suggests that agreeableness might be a country-specific factor that affects one's educational and career success in the opposite direction.

\subsection{Personality Traits, Company Size, Employment Status, and Men’s Income}

We further investigated how this contradictory personality trait, agreeableness, affects annual income in Japan and the United States. First, we examined whether personality traits work differently in respondents as a function of company size (Table 4). Companies with many employees tend to give higher evaluations to agreeable employees who can cooperate with other colleagues. Rewarding agreeableness in large-sized companies would have a positive effect on annual income. As shown in Tables 3 and 4, agreeableness was consistently positive among Japanese male workers and, in particular, those working for large-sized companies. We observed an interesting contrast in the United States, where agreeableness seemed to operate as a penalty against raising the annual income of American male workers, except of those working for large companies (1,000 employees or more), where agreeableness was rewarding for income as well. In fact, we observed a negative effect of agreeableness on annual income only among Americans working for small-sized companies. Although employees at large-sized companies were rewarded for being agreeable compared to those working at smaller-sized companies, the total effect was close to zero. As for smaller-sized companies, in addition to the effect of agreeableness, being extroverted and conscientious in Japan and emotionally stable in the United States rewarded the earnings of their respective male employees.

We further examined whether personality trait effects differed by employment status (ordinary employees vs. managers) because a certain personality trait might be essential for those holding managerial positions. Table 5 (columns 1 and 2) shows interaction terms between each personality trait and a binary indicator of managers (=1), with the base representing ordinary employees. We found that extroverted and agreeable ordinary employees in Japan and disagreeable and emotionally stable ordinary employees in the United States earned more. However, we observed no statistically significant difference in personality trait effects between ordinary employees and managers in both countries.

Thus far, advantageous personality traits differed by company size, but very little by employment status. More specifically, although the effect of agreeableness did not differ between ordinary employees and managers, being agreeable seems to be rewarded by higher income in large-sized companies compared to small-sized companies in both Japan and the United States. These results led us to ask whether the effect of agreeableness at large-sized companies would differ by employment status. In other words, was the positive average effect of agreeableness at large-sized companies more pronounced among ordinary employees or among managers? To answer this question, Table 5 (columns 3 and 4 ) also includes 
interaction terms between agreeableness, a binary indicator of managers $(=1)$, and a binary indicator of company size with 1000 employees or more $(=1)$. We found that agreeableness was advantageous for those working for large companies in both Japan and America, and that this positive effect was significant even in ordinary employees of large private companies/organizations in both countries. columns 1 and 2 of Table 5 show no significant difference between ordinary employees and managers, which suggests that being agreeable is rewarded at large-sized companies, regardless of employment status, more than at small-sized companies.

To investigate which personality traits affect the probability of being promoted to a management position, we conducted probit regressions with a dependent variable equal to one for a respondent working in a management position at the time of the survey and 0 otherwise (see Table 6). Overall, extroversion in men was a significant personality trait affecting career advancement in both countries, regardless of company size. In fact, extroversion was more important than any other personality trait for management positions in Japan and the United States. Therefore, although agreeable employees at large companies are more likely to earn more, agreeableness does not necessarily improve career advancement. In fact, we might interpret agreeableness as a trait that directly affects job performance and productivity, which translates into higher earnings, rather than having indirect effects on career advancement or occupational choice.

\subsection{Effects of Personality Traits on Happiness}

We further examined the effect of agreeableness on outcomes other than economic rewards, such as income growth and career advancement. Thus far, our results have revealed that being agreeable is not rewarding for women and is not rewarding for men in the United States (see Table 3). However, Table 7 shows that being agreeable increased degree of happiness in women of both countries. This positive effect remains significant even when controlling for annual income. Thus, although agreeableness does not affect income, and may even have a negative relation with income, among women in Japan and the United States, it might have positive effects on other outcomes, such as subjective well-being. Agreeableness increases income for men in Japan and has a significantly positive effect on happiness, with and without controlling for annual income. Even when labor-related variables, including income, are held equal, this particular personality trait was an important factor that increased the subjective feeling of happiness as well as economic outcomes among Japanese men. In contrast, conscientiousness, which best predicts later outcomes, is not correlated with happiness. Thus, conscientiousness might increase years of schooling and income through hard work, but it does not necessarily directly increase the feeling of happiness. 


\section{Discussion}

Studies have given much attention to the predictive power of intelligence measures when evaluating cumulative human capital. However, it has been argued that no single measure of cognitive ability can predict much of the variance in educational and labor market outcomes. Because most of the remaining variance is not explained by measurement error, much room remains for other determinants of success. This study considered soft skills as possible predictors of the unexplained variance in educational and labor market outcomes. In this study, soft skills were characterized by scores for the Big Five personality traits, a widely accepted taxonomy in personality trait research. Our estimated results suggest that personality traits are significantly correlated with later outcomes. Previous studies using data collected in different countries have yielded different results, possibly because the authors controlled for different covariates, or because some significant country differences exist. In the present study, we evaluated the relation between personality trait and various outcomes using the same covariates. Overall, our results revealed substantial similarities in the effect of personality traits on both educational and labor market outcomes across both countries, which is consistent with previous empirical studies, notwithstanding a few contradictory results between Japan and the United States.

In these countries, conscientiousness, openness to experiences, and/or emotional stability are correlated with educational attainment despite differences in the relative importance of each. In previous literature, conscientiousness was the best predictor of later outcomes. Implications of the effects of openness to experiences and emotional stability can be explained in terms of their relation to degree of intelligence, interest in learning, and self-control, all of which play an important role in cognitive ability and adolescent schooling decisions. In addition, the effects of personality traits on labor market outcomes are very similar between the two analyzed countries. In both countries, men with a high degree of conscientiousness seemed to earn more, and extroversion best predicted the probability of promotion to a management position among men in both countries. These results are consistent with general findings in extant studies on personality traits and career success. However, no established empirical consensus exists in the still advancing study of personality traits. Nonetheless, the effects of personality traits that have been most commonly identified in previously research as significant for educational and labor market outcomes were similar to those in the countries analyzed here.

Despite these similarities, Japan and the United States exhibited distinct differences, most notably in the effect of agreeableness. Japanese respondents scored noticeably higher in agreeableness than American respondents, and agreeableness was a particularly important predictor for schooling and income in Japanese men. This finding contrasts with that of a substantial body of literature, in which agreeableness was a less important predictor of educational attainment. In contrast, agreeableness 
operated in the opposite direction in the United States, which suggests the existence of country-specific determinants of success. Woessmann, Luedemann, Schuetz, and West (2009) argued that students' personality traits might depend on characteristics of their educational environment, such as autonomy and degree of accountability. Rockoff, Jacob, Kane, and Staiger (2008) emphasized the importance of teacher influence on the development of students' noncognitive skills. If this holds true, teaching style and educational philosophy might contribute to the unique variance in personality traits affecting educational outcomes in Japan.

We focused on how agreeableness, which seems particularly important for schooling in Japan, affected labor market outcomes, and whether agreeableness would continue its negative correlation in the American labor market. In Japan, being agreeable had a positive effect on years of schooling. Japanese men who were agreeable were more likely to enter a four-year university. Furthermore, they earned more, even when controlling for occupation, employment type, years of employment, company size, and hours worked. In contrast, being agreeable in the United States had a negative effect on years of schooling. Although this negative effect was not statistically significant for American male students, it negatively affected their income. This penalty continued even when occupation, employment type, years of employment, company size, and age were held equal. Thus, being agreeable has an income-lowering effect no matter what kind of job one has or how long one has worked.

To investigate the channels through which agreeableness is associated with labor market outcomes, we analyzed its effects on annual income by company size and employment status. We observed a premium for being agreeable among those working for large companies in both Japan and the United States. This result did not change even with type of occupation and other labor-related variables held constant. Agreeable employees at large companies were likely to earn more than those at small-sized companies, but we found no statistical difference in the effect of agreeableness between ordinary employees and managers. For promotion to a management position, extroversion was more important than any other personality trait. These findings suggest that employees of large-sized companies are directly rewarded for being agreeable through their income, rather than indirectly through occupational choice or career advancement. Furthermore, agreeableness affects the subjective feeling of happiness as well as economic outcomes. In particular, Japanese men who are agreeable earn more and feel happier. Even though women's income in both countries was negatively associated with agreeableness, it increased the degree of their subjective well-being. Therefore, although agreeableness did not affect income in Japanese women and it had a negative relation with income among American women, it can positively affect other later outcomes such as subjective well-being. 
In summary, we identified the possibility of a premium for being agreeable among employees working for large companies in Japan and America. The significance of agreeableness still existed even when type of occupation and other labor-related variables were held constant. In contrast, a wage premium is not necessarily connected with career advancement, which means that a wage premium was not the result of promotion. Results for income growth and career advancement suggest that agreeableness might directly affect job performance and increase productivity of employees of large companies, which in turn reflects their annual income. However, some limitations restrict generalizability of the present findings. Although some extant studies have proven the stability of personality traits at working age and have suggested that examination of personality traits remain stable under fluctuating economic events, it is difficult to conclude that a personality trait affects labor outcomes or vice versa, or that they mutually influence each other. Caution is called for before concluding that the results presented here suggest a complete causal relation. 


\section{References}

Ackerman, P. L., and Heggestad, E. D. (1997). Intelligence, personality, and interests: Evidence for overlapping traits. Psychological Bulletin, 121, 219-245.

Almlund, M., Duckworth, A. L., Heckman, J. J., and Kautz, T. (2011). Personality psychology and economics. In Hanushek, E. A., Machin, S., and Wößmann, L. (Eds.), Handbook of the Economics of Education (pp. 1-181). Amsterdam, Netherlands: Elsevier.

Barón, J. D., and Cobb-Clark, D. A. (2010). Are young people's educational outcomes linked to their sense of control? IZA Discussion Papers 4907, Institute for the Study of Labor (IZA).

Borghans, L., Duckworth, A. L., Heckman, J.J., and ter Weel, B. (2008). The economics and psychology of personality traits. Journal of Human Resources, 43 (4), 972-1059.

Borghans, L., Golsteyn, B. H. H., Heckman, J. J., and Humphries, J. E. (2011). Identification problems in personality psychology. Personality and Individual Differences, 51, 315-320 (Special Issue on Personality and Economics).

Borghans, L., Meijers, F. and ter Weel, B. (2006). The role of noncognitive skills in explaining cognitive test scores. Economic Inquiry, 46(1), 2-12.

Bouchard, T. J., Jr., and Loehlin, J. C. (2001). Genes, evolution, and personality. Behavior Genetics, $31,243-273$.

Bowles, S., Gintis, H., and Osborne, M. (2001). The determinants of earnings: A behavioral approach. Journal of Economic Literature, 39(4), 1137-1176.

Burisch, M. (1997). Test length and validity revisited. European Journal of Personality, 11, 303-315.

Carneiro, P., Crawford, C., and Goodman, A. (2007). The Impact of early cognitive and non-cognitive skills on later outcomes. CEE Discussion Papers, No. 0092.

Caspi, A. (1997). Personality development across the life course. In Damon, W. (Ser. Ed.), and Eisenberg, N. (Vol. Ed.), Handbook of Child Psychology, Vol. 3: Social, Emotional and Personality Development ( $5^{\text {th }}$ Edition). New York, NY: Wiley.

Cebi, M. (2007). Locus of control and human capital investment revisited. Journal of Human Resources, 42(4), 919-932.

Chetty, R., Friedman, J. N., Hilger, N., Saez, E., Schanzenbach, D. W., and Yagan, D. (2011) How Does Your Kindergarten Classroom Affect Your Earnings? Evidence from Project STAR. Quarterly Journal of Economics, 126(4), 1593-1660.

Chamorro-Premuzic, T., and Furnham, A. (2005). Personality and Intellectual Competence. Mahwah, NJ: Lawrence Erlbaum Associates. 
Coleman, M., and DeLeire, T. (2003). An economic model of locus of control and the human capital investment decision. Journal of Human Resources, 38(3), 701-721.

Cobb-Clark, D. A., and Schurer, S. (2012). The stability of big-five personality traits. Economics Letters, 115, 11-15.

Conard, M. A. (2006). Aptitude is not enough: How personality and behavior predict academic performance. Journal of Research in Personality, 40, 339-346.

Costa, P. T., Terracciano A, and McCrae, R. R. (2001). Gender differences in personality traits across cultures: Robust and surprising findings. Journal of Personality and Social Psychology, 81, 322-331.

Dee, T. S., and West, M. R. (2011). The non-cognitive returns to class size. Education Evaluation and Policy Analysis, 33(1), 23-46.

Duckworth, A. L., and Weir, D. R. (2010). Personality, lifetime earnings, and retirement wealth. Michigan Retirement Research Center Paper, No. 2010-2235.

Epstein, S. (1979). The stability of behavior: I. On predicting most of the people much of the time. Journal of Personality and Social Psychology, 37(7), 1097-1126.

Farsides, T., and Woodfield, R. (2003). Individual differences and undergraduate academic success: The roles of personality, intelligence, and application. Personality and Individual Differences, 34, 1225-1243.

Feingold, A. (1994). Gender differences in personality - a meta analysis. Psychological Bulletin, 116, 429-456

Fletcher, J. M. (2013). The effects of personality traits on adult labor market outcomes: Evidence from siblings. Journal of Economic Behavior and Organization, 89, 122-135.

Goldberg, L. R., Sweeney, D., Merenda, P. F., and Hughes, J. E. Jr. (1998). Demographic variables and personality: The effects of gender, age, education, and ethnic/racial status on self-descriptions of personality attributes. Personality and Individual Differences, 24(3), 393-403.

Goff, M., and Ackerman, P. L. (1992). Personality-intelligence relations: Assessment of typical intellectual engagement. Journal of Educational Psychology, 84, 537-553.

Gray, E. K., and Watson, D. (2002). General and specific traits of personality and their relation to sleep and academic performance. Journal of Personality, 70, 177-206.

Gosling, S. D., Rentfrow, P. J., William, B., and Swann Jr, W. B. (2003). A very brief measure of the Big-Five personality domains. Journal of Research in Personality, 37, 504-528. 
Hampson, S. E., Goldberg, L. R., Vogt, T. M., and Dubanoski, J. P. (2007). Mechanisms by which childhood personality traits influence adult health status: Educational attainment and healthy behaviors. Health Psychology, 26(1), 121-125.

Heckman, J. J. (1999). Policies to foster human Capital. NBER Working Papers, No. 7288.

Heckman, J. J., Hsee, J., and Rubinstein, Y. (2001). The GED is a mixed signal: the effect of cognitive and noncognitive skills on human capital and labor market outcomes. The University of Chicago.

Heckman, J. J., and Kautz, T. (2012). Hard evidence on soft skills. Labour Economics, 19, 451-464.

Heckman, J. J., Moon, S. H., Pinto, R., Savelyev, P. A., and Yavitz, A. Q. (2010). The rate of return to the HighScope Perry Preschool Program. Journal of Public Economics, 94 (1-2), 114-128.

Heckman, J. J., Stixrud, N., and Urzua, S. (2006). The effects of cognitive and noncognitive abilities on labor market outcomes and social behavior. Journal of Labor Economics, 24(3), 411-482.

Heineck, G., and Anger, S. (2010). The returns to cognitive abilities and personality traits in Germany. Labour Economics, 17(3), 535-546.

John, O.P., Srivastava, S. (1999). The Big Five trait taxonomy: History, measurement and theoretical perspectives. In: Pervin, L.A., John, O.P. (Eds.), Handbook of Personality: Theory and Research. The Guilford Press, New York, pp. 102-138 (Chapter 4).

Judge, T. A., Higgins, C. A., Thoresen, C. J., and Barrick, M. R. (1999). The big five personality traits, general mental ability, and career success across the life span. Personnel Psychology, 52, 621-652.

Lee, S. Y., and Ohtake, F. (2014). The effects of personality traits and behavioral characteristics on schooling, earnings, and career Promotion, RIETI Discussion Paper Series 14-E-023.

Lievens, F., Dilchert, S., and Ones, D. S. (2009). Personality scale validities increase throughout medical school. Journal of Applied Psychology, 94(6), 1514-1535.

Lounsbury, J. W., Sundstrom, E., Loveland, J. M., and Gibson, L. W. (2003). Intelligence, Big Five personality traits, and work drive as predictors of course grade. Personality and Individual Differences, 35, 1231-1239.

Muller, G., and Plug, E. (2006). Estimating the effect of personality on male and female earnings. Industrial and Labor Relations Review, 60(1), 3-22.

O’Connor, M. C., and Paunonen, S. V. (2007). Big Five personality predictors of post-secondary academic performance. Personality and Individual Differences, 43, 971-990. 
Poropat, A. E. (2009). A meta-analysis of the Five-Factor Model of personality and academic performance. Psychological Bulletin, 135(2), 322-338.

Roberts, B. W., and Jackson, J. J. (2008). Sociogenomic personality psychology. Journal of Personality, 76(6), 1523-1544.

Roberts, B. W., Kuncel, N. R., Shiner, R., Caspi, A., and Goldberg, L. R. (2007). The power of personality: The comparative validity of personality traits, socioeconomic status, and cognitive ability for predicting important life outcomes. Perspectives on Psychological Science, 2, 313-345.

Rockoff, J. E., Jacob, B. A., Kane, T. J., and Staiger, D. O. (2010). The impact of entrepreneurship education on entrepreneurship skills and motivation, NBER Working Papers, No. 14485.

Semykina, A., and Linz, S. J. (2007). Gender differences in personality and earnings: Evidence from Russia. Journal of Economic Psychology, 28(3), 387-410.

Soldz, S., and Vaillant G. E. (1999). The Big Five personality traits and the life course: A 45-year longitudinal study. Journal of Research in Personality, 33, 208-232.

Uysal, S. D., and Pohlmeier, W. (2011). Unemployment duration and personality, Journal of Economic Psychology, 32(6), 980-992.

van Eijck, K., and de Graaf, P. M. (2004). The Big Five at school: The impact of personality on educational attainment. Netherlands' Journal of Social Sciences, 40(1), 24-40.

Woessmann, E., Luedemann, E., Schuetz, G., and West, M. R. (2007). School accountability, autonomy, choice and the level of student achievement: International Evidence from PISA 2003. OECD Education Working Papers, No. 13.

Yates, S. M., Yates, G. C. R., and Lippett, R. M. (1995). Explanatory style, ego-orientation, and primary mathematics achievement. Educational Psychology and International Journal of Experimental Educational Psychology, 15, 23-35. 


\section{Dependent variables}

Years of schooling

College (=1)

Graduate school (=1)

Annual Income (log)

Promoted to management position at private companies

Big Five personality

$$
\begin{aligned}
& \text { Extroversion } \\
& \text { Agreeableness } \\
& \text { Conscientiousness } \\
& \text { Emotional Stability }
\end{aligned}
$$

Openness to Experiences

Socio-economic variables

Age

Age square

Parental Education

$\frac{\text { Labor market variables }}{\text { (Type of Occupation) }}$

\section{Office and administrative support}

Sales and related occupations

Management, business, and financial operations

Professional and related occupations

Service occupations

Construction, extraction, and maintenance Farming, fishing, and forestry

(Employment Type)

Employee of private company or organization

Government employee

Management position

Self-employed

Family business employee (in self-employed business)

(Work Experience and Company Size)

\begin{tabular}{|c|c|c|c|c|c|c|c|c|c|c|c|}
\hline \multicolumn{4}{|l|}{ Japan } & \multicolumn{6}{|c|}{ U.S. } & \multirow{2}{*}{\multicolumn{2}{|c|}{ Females }} \\
\hline Whole & mple & & & Fen & & Whole & & $\mathrm{Mc}_{\mathrm{c}}$ & & & \\
\hline Mean & S.D. & Mean & S.D. & Mean & S.D. & Mean & S.D. & Mean & S.D. & Mean & S.D. \\
\hline 13.39 & 2.00 & 13.71 & 2.27 & 13.13 & $\overline{1.71}$ & 14.43 & 2.42 & 14.57 & 2.61 & 14.32 & 2.24 \\
\hline 0.27 & 0.44 & 0.40 & 0.49 & 0.16 & 0.37 & 0.39 & 0.49 & 0.42 & 0.49 & 0.36 & 0.48 \\
\hline 0.02 & 0.13 & 0.03 & 0.17 & 0.01 & 0.09 & 0.13 & 0.34 & 0.15 & 0.36 & 0.12 & 0.32 \\
\hline 5.63 & 0.91 & 6.09 & 0.66 & 5.07 & 0.86 & 5.95 & 0.86 & 6.14 & 0.81 & 5.75 & 0.87 \\
\hline 0.17 & 0.38 & 0.28 & 0.45 & 0.04 & 0.20 & 0.17 & 0.37 & 0.20 & 0.40 & 0.14 & 0.35 \\
\hline 4.09 & 1.29 & 3.96 & 1.29 & 4.20 & 1.28 & 3.96 & 1.45 & 3.91 & 1.47 & 4.00 & 1.44 \\
\hline 4.99 & 0.93 & 4.92 & 0.95 & 5.04 & 0.91 & 5.06 & 1.22 & 4.79 & 1.24 & 5.28 & 1.16 \\
\hline 3.99 & 1.06 & 4.00 & 1.05 & 3.97 & 1.07 & 5.75 & 1.15 & 5.61 & 1.14 & 5.87 & 1.14 \\
\hline 4.01 & 1.03 & 4.11 & 1.01 & 3.92 & 1.04 & 4.84 & 1.35 & 4.90 & 1.37 & 4.79 & 1.33 \\
\hline 3.89 & 1.07 & 4.03 & 1.04 & 3.78 & 1.07 & 4.69 & 1.16 & 4.70 & 1.14 & 4.67 & 1.19 \\
\hline 50.34 & 9.57 & 50.85 & 9.36 & 49.92 & 9.73 & 49.75 & 9.46 & 49.68 & 9.47 & 49.81 & 9.46 \\
\hline 2625.5 & 947.4 & 2673.1 & 930.7 & 2586.2 & 959.5 & 2564.6 & 916.2 & 2557.2 & 916.2 & 2570.7 & 916.6 \\
\hline 0.55 & 0.50 & 0.00 & 0.00 & 1.00 & 0.00 & 0.54 & 0.50 & 0.00 & 0.00 & 1.00 & 0.00 \\
\hline 11.07 & 1.92 & 10.95 & 1.96 & 11.18 & 1.89 & 12.51 & 2.13 & 12.60 & 2.17 & 12.43 & 2.09 \\
\hline 0.22 & 0.41 & 0.14 & 0.34 & 0.31 & 0.46 & 0.14 & 0.35 & 0.03 & 0.17 & 0.25 & 0.43 \\
\hline 0.11 & 0.31 & 0.09 & 0.28 & 0.14 & 0.35 & 0.12 & 0.32 & 0.11 & 0.31 & 0.13 & 0.34 \\
\hline 0.12 & 0.33 & 0.21 & 0.41 & 0.02 & 0.12 & 0.15 & 0.36 & 0.18 & 0.38 & 0.13 & 0.34 \\
\hline 0.21 & 0.41 & 0.21 & 0.41 & 0.21 & 0.41 & 0.29 & 0.45 & 0.29 & 0.45 & 0.29 & 0.46 \\
\hline 0.19 & 0.39 & 0.16 & 0.36 & 0.23 & 0.42 & 0.19 & 0.39 & 0.19 & 0.40 & 0.18 & 0.38 \\
\hline 0.14 & 0.34 & 0.18 & 0.39 & 0.08 & 0.27 & 0.10 & 0.30 & 0.19 & 0.39 & 0.01 & 0.09 \\
\hline 0.02 & 0.13 & 0.02 & 0.14 & 0.02 & 0.13 & 0.01 & 0.12 & 0.02 & 0.13 & 0.01 & 0.10 \\
\hline 0.69 & 0.46 & 0.67 & 0.47 & 0.72 & 0.45 & 0.60 & 0.49 & 0.56 & 0.50 & 0.63 & 0.48 \\
\hline 0.10 & 0.30 & 0.11 & 0.31 & 0.09 & 0.29 & 0.18 & 0.38 & 0.17 & 0.37 & 0.19 & 0.39 \\
\hline 0.05 & 0.21 & 0.07 & 0.25 & 0.02 & 0.14 & 0.12 & 0.33 & 0.16 & 0.36 & 0.09 & 0.29 \\
\hline 0.10 & 0.31 & 0.12 & 0.33 & 0.08 & 0.27 & 0.09 & 0.28 & 0.10 & 0.31 & 0.07 & 0.25 \\
\hline 0.05 & 0.22 & 0.02 & 0.15 & 0.09 & 0.28 & 0.01 & 0.11 & 0.01 & 0.09 & 0.02 & 0.14 \\
\hline 23.97 & 3.98 & 24.32 & 3.30 & 23.55 & 4.65 & 13.07 & 9.74 & 13.40 & 10.14 & 12.73 & 9.31 \\
\hline 0.17 & 0.38 & 0.21 & 0.40 & 0.13 & 0.41 & 0.31 & 0.46 & 0.31 & 0.05 & 0.32 & 0.47 \\
\hline
\end{tabular}

Years of work experience at the current workplace

Size of company ( $=1$ if the number of employees is more thar

Note. The Big Five personality traits and socioeconomic variables are described with samples used to analyze educational attainment (Table 2, column 2; Japan = 3,199; U.S. = 1,574). Annual income,

management position at private companies, and labor market variables are summarized with the sample used to analyze determinants of annual income. 
Table 2. Determinants of Educational Attainment in Japan and the United States

\begin{tabular}{|c|c|c|c|c|c|c|c|c|}
\hline $\begin{array}{l}\text { Independent Variables } \\
\text { Japan } \\
\text { Regression Model: OLS/Probit }\end{array}$ & \multicolumn{2}{|c|}{ Years of Schooling } & \multicolumn{2}{|c|}{$\frac{\text { Years of Schooling }}{\text { w/t Parental eduation }}$} & \multicolumn{2}{|c|}{$\begin{array}{l}\text { College Graduates } \\
\text { w/t Parental eduation }\end{array}$} & \multicolumn{2}{|c|}{$\frac{\text { Attainment of grad. level of edu. }}{\text { w/t Parental eduation }}$} \\
\hline \multicolumn{9}{|l|}{ Big 5 Personality } \\
\hline Extroversion & $\begin{array}{l}-0.0280 \\
(0.051)\end{array}$ & $\begin{array}{l}0.0111 \\
(0.033)\end{array}$ & $\begin{array}{l}-0.0555 \\
(0.049)\end{array}$ & $\begin{array}{l}-0.0364 \\
(0.032)\end{array}$ & $\begin{array}{l}-0.0202 \\
(0.030)\end{array}$ & $\begin{array}{l}-0.0286 \\
(0.033)\end{array}$ & $\begin{array}{l}-0.1451^{* *} \\
(0.060)\end{array}$ & $\begin{array}{l}0.2425^{* *} \\
(0.097)\end{array}$ \\
\hline Agreeableness & $\begin{array}{l}0.2033 * * * \\
(0.066)\end{array}$ & $\begin{array}{l}0.0955^{* *} \\
(0.044)\end{array}$ & $\begin{array}{l}0.1982 * * * \\
(0.062)\end{array}$ & $\begin{array}{l}0.0368 \\
(0.042)\end{array}$ & $\begin{array}{l}0.1132 * * * \\
(0.040)\end{array}$ & $\begin{array}{l}-0.0084 \\
(0.046)\end{array}$ & $\begin{array}{l}-0.0062 \\
(0.079)\end{array}$ & $\begin{array}{l}-0.1190 \\
(0.123)\end{array}$ \\
\hline Conscientiousness & $\begin{array}{l}0.0852 \\
(0.062)\end{array}$ & $\begin{array}{l}-0.0125 \\
(0.040)\end{array}$ & $\begin{array}{l}0.0865 \\
(0.059)\end{array}$ & $\begin{array}{l}-0.0014 \\
(0.037)\end{array}$ & $\begin{array}{l}0.0955^{* * *} \\
(0.036)\end{array}$ & $\begin{array}{l}0.0336 \\
(0.039)\end{array}$ & $\begin{array}{l}0.0579 \\
(0.071)\end{array}$ & $\begin{array}{l}-0.0192 \\
(0.105)\end{array}$ \\
\hline Openness to Experiences & $\begin{array}{l}0.1132^{*} \\
(0.063)\end{array}$ & $\begin{array}{l}0.0753 * \\
(0.039)\end{array}$ & $\begin{array}{l}0.0629 \\
(0.061)\end{array}$ & $\begin{array}{l}0.0717^{*} \\
(0.037)\end{array}$ & $\begin{array}{l}-0.0021 \\
(0.037)\end{array}$ & $\begin{array}{l}0.0038 \\
(0.038)\end{array}$ & $\begin{array}{l}0.1595^{* *} \\
(0.070)\end{array}$ & $\begin{array}{l}-0.0363 \\
(0.101)\end{array}$ \\
\hline $\begin{array}{l}\text { Years of schooling } \\
\text { of parents }\end{array}$ & - & - & $\begin{array}{l}0.4510^{* * * *} \\
(0.028)\end{array}$ & $\begin{array}{l}0.3668 * * * \\
(0.020)\end{array}$ & $\begin{array}{l}0.2553 * * * \\
(0.020)\end{array}$ & $\begin{array}{l}0.2757^{* * * *} \\
(0.021)\end{array}$ & $\begin{array}{l}0.1332 * * * \\
(0.034)\end{array}$ & $\begin{array}{l}0.1556^{* * * *} \\
(0.054)\end{array}$ \\
\hline Observations & 1,522 & 1,844 & 1,445 & 1,754 & 1,442 & 1,760 & 1,445 & 1,754 \\
\hline R-squared & 0.030 & 0.054 & 0.162 & 0.194 & & & & \\
\hline \multicolumn{9}{|l|}{ Big 5 Personality } \\
\hline Extroversion & $\begin{array}{l}-0.0888 \\
(0.069)\end{array}$ & $\begin{array}{l}0.0224 \\
(0.054)\end{array}$ & $\begin{array}{l}-0.0998 \\
(0.067)\end{array}$ & $\begin{array}{l}-0.0528 \\
(0.052)\end{array}$ & $\begin{array}{l}-0.0430 \\
(0.035)\end{array}$ & $\begin{array}{l}-0.0385 \\
(0.034)\end{array}$ & $\begin{array}{l}0.0099 \\
(0.041)\end{array}$ & $\begin{array}{l}-0.0183 \\
(0.042)\end{array}$ \\
\hline Agreeableness & $\begin{array}{l}-0.0924 \\
(0.083)\end{array}$ & $\begin{array}{l}-0.1121 \\
(0.073)\end{array}$ & $\begin{array}{l}-0.1017 \\
(0.082)\end{array}$ & $\begin{array}{l}-0.1537 * * \\
(0.068)\end{array}$ & $\begin{array}{l}-0.0537 \\
(0.045)\end{array}$ & $\begin{array}{l}-0.1320 * * * \\
(0.048)\end{array}$ & $\begin{array}{l}-0.0345 \\
(0.054)\end{array}$ & $\begin{array}{l}0.0099 \\
(0.059)\end{array}$ \\
\hline Conscientiousness & $\begin{array}{l}0.2721 * * * \\
(0.089)\end{array}$ & $\begin{array}{l}0.2040 * * * \\
(0.075)\end{array}$ & $\begin{array}{l}0.2381 * * * \\
(0.086)\end{array}$ & $\begin{array}{l}0.2078^{* * *} \\
(0.069)\end{array}$ & $\begin{array}{l}0.1695^{* * * *} \\
(0.049)\end{array}$ & $\begin{array}{l}0.1347^{* * *} \\
(0.045)\end{array}$ & $\begin{array}{l}0.1130^{*} \\
(0.061)\end{array}$ & $\begin{array}{l}0.1307 * * \\
(0.060)\end{array}$ \\
\hline Emotional Stability & $\begin{array}{l}0.2655 * * * \\
(0.078)\end{array}$ & $\begin{array}{l}0.1456 * * \\
(0.065)\end{array}$ & $\begin{array}{l}0.2585 * * * \\
(0.075)\end{array}$ & $\begin{array}{l}0.1268^{* * *} \\
(0.061)\end{array}$ & $\begin{array}{l}0.1219 * * * \\
(0.042)\end{array}$ & $\begin{array}{l}0.0729 * \\
(0.042)\end{array}$ & $\begin{array}{l}0.1242^{* *} \\
(0.052)\end{array}$ & $\begin{array}{l}-0.0230 \\
(0.052)\end{array}$ \\
\hline Openness to Experiences & $\begin{array}{l}0.1060 \\
(0.087)\end{array}$ & $\begin{array}{l}0.0765 \\
(0.065)\end{array}$ & $\begin{array}{l}0.0844 \\
(0.084)\end{array}$ & $\begin{array}{l}0.0888 \\
(0.060)\end{array}$ & $\begin{array}{l}-0.0161 \\
(0.047)\end{array}$ & $\begin{array}{l}0.0462 \\
(0.044)\end{array}$ & $\begin{array}{l}0.0497 \\
(0.057)\end{array}$ & $\begin{array}{l}0.0464 \\
(0.055)\end{array}$ \\
\hline $\begin{array}{l}\text { Years of schooling } \\
\text { of parents }\end{array}$ & - & - & $\begin{array}{l}0.3970 * * * \\
(0.045)\end{array}$ & $\begin{array}{l}0.4269 * * * \\
(0.033)\end{array}$ & $\begin{array}{l}0.1725^{* * *} \\
(0.025)\end{array}$ & $\begin{array}{l}0.2624^{* * * *} \\
(0.026)\end{array}$ & $\begin{array}{l}0.1223 * * * \\
(0.028)\end{array}$ & $\begin{array}{l}0.1464 * * * \\
(0.029)\end{array}$ \\
\hline Observations & 754 & 884 & 717 & 857 & 717 & 857 & 717 & 857 \\
\hline
\end{tabular}

signifies parental educational level. Robust standard errors are in parentheses. ${ }^{* * *} \mathrm{p}<0.01,{ }^{* *} \mathrm{p}<0.05$, ${ }^{*} \mathrm{p}<0.1$. 
Table 3. Effects of (Non)Cognitive Skills on Annual Income

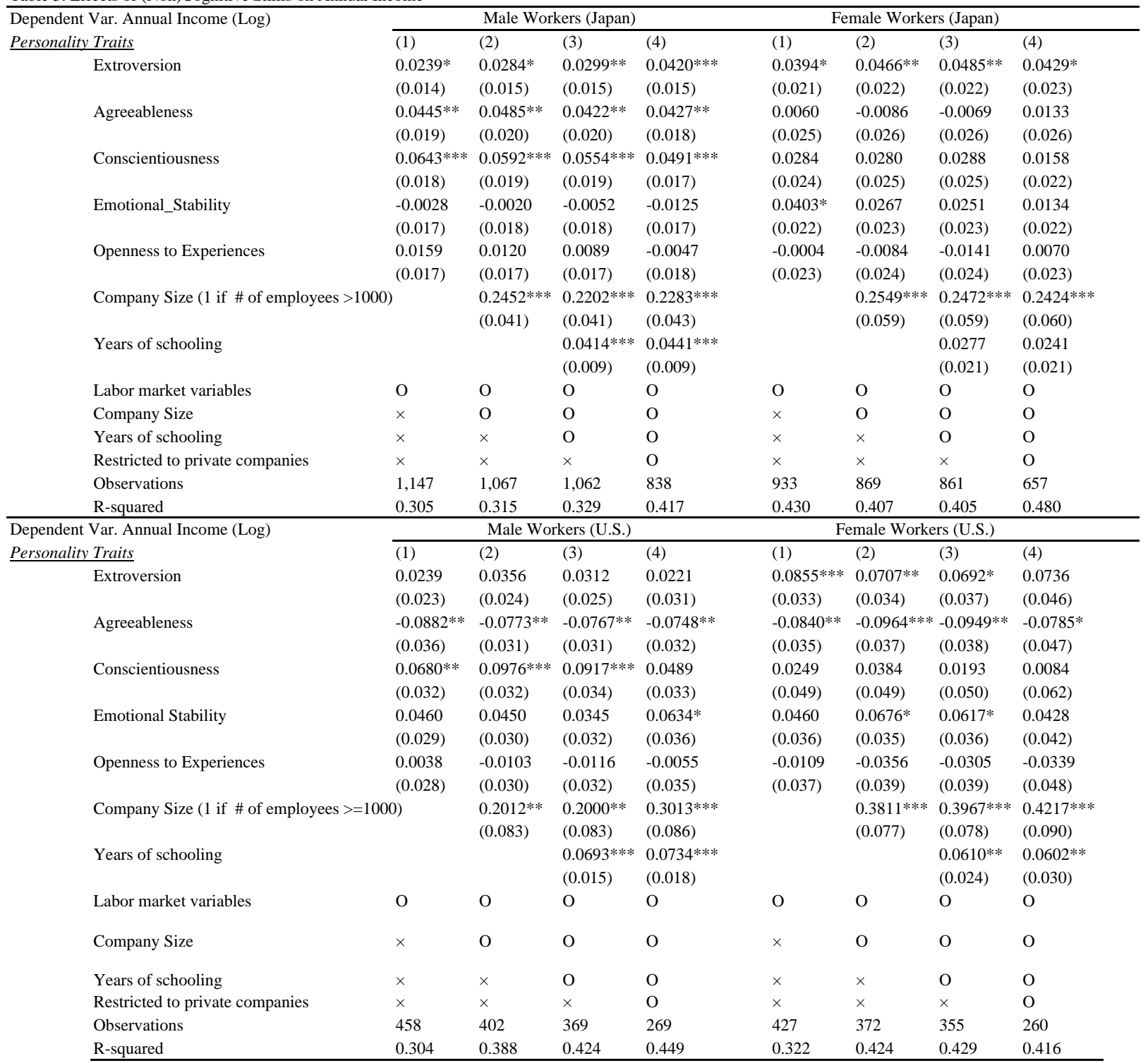

Note. Estimations are additionally controlled for socioeconomic variables (age and its square, type of occupation, employment type, full-time employment, years of employment at current workplace, working hours, and race dummies [only American samples]). Robust standard errors are in parentheses. ${ }^{* * *} \mathrm{p}<0.01,{ }^{* *} \mathrm{p}<0.05$, 
Table 4. Effects of (Non)Cognitive Skills on Annual Income by Company Size

\begin{tabular}{|c|c|c|}
\hline \multirow[t]{2}{*}{ Depdent Variables } & \multicolumn{2}{|c|}{ Annual Income (Log) } \\
\hline & $\begin{array}{l}\text { Japan } \\
(1)\end{array}$ & $\begin{array}{l}\text { U.S. } \\
(2)\end{array}$ \\
\hline \multicolumn{3}{|l|}{ Personality Traits } \\
\hline Extroversion & $\begin{array}{l}0.0516 * * * \\
(0.016)\end{array}$ & $\begin{array}{l}-0.0187 \\
(0.043)\end{array}$ \\
\hline Agreeableness & $\begin{array}{l}0.0225 \\
(0.021)\end{array}$ & $\begin{array}{l}-0.1190^{* *} \\
(0.048)\end{array}$ \\
\hline Conscientiousness & $\begin{array}{l}0.0640^{* * *} \\
(0.019)\end{array}$ & $\begin{array}{l}0.0720 \\
(0.047)\end{array}$ \\
\hline Emotional Stability & $\begin{array}{l}-0.0135 \\
(0.019)\end{array}$ & $\begin{array}{l}0.1047^{* *} \\
(0.048)\end{array}$ \\
\hline Openness to Experiences & $\begin{array}{l}-0.0049 \\
(0.020)\end{array}$ & $\begin{array}{l}-0.0372 \\
(0.049)\end{array}$ \\
\hline \multicolumn{3}{|c|}{ Interaction between "1000 Employees and more $(=1) "$ and Personality } \\
\hline 1000 Employees and more $(=1) \times$ Extroversion & $\begin{array}{l}-0.0207 \\
(0.039)\end{array}$ & $\begin{array}{l}0.0956 * \\
(0.052)\end{array}$ \\
\hline 1000 Employees and more $(=1) \times$ Agreeableness & $\begin{array}{l}0.0690^{*} \\
(0.041)\end{array}$ & $\begin{array}{l}0.1107^{*} \\
(0.063)\end{array}$ \\
\hline 1000 Employees and more $(=1) \times$ Conscientiousness & $\begin{array}{l}-0.0505 \\
(0.043)\end{array}$ & $\begin{array}{l}-0.0707 \\
(0.063)\end{array}$ \\
\hline 1000 Employees and more $(=1) \times$ Emotional Stability & $\begin{array}{l}0.0161 \\
(0.041)\end{array}$ & $\begin{array}{l}-0.1032 * \\
(0.057)\end{array}$ \\
\hline 1000 Employees and more $(=1) \times$ Openness to Experiences & $\begin{array}{l}-0.0135 \\
(0.041)\end{array}$ & $\begin{array}{l}0.1190 \\
(0.073)\end{array}$ \\
\hline \multicolumn{3}{|l|}{ Company Size } \\
\hline 1000 Employees and more $(=1)$ & $\begin{array}{l}0.1418 \\
(0.277)\end{array}$ & $\begin{array}{l}-0.2560 \\
(0.500)\end{array}$ \\
\hline$\frac{\text { Educational Background }}{\text { Years of Schooling }}$ & $\begin{array}{l}0.0426 * * * \\
(0.009)\end{array}$ & $\begin{array}{l}0.0708 * * * \\
(0.018)\end{array}$ \\
\hline Labor Market Variables & & \\
\hline Working Hours & $\begin{array}{l}0.0033^{*} \\
(0.002) \\
\end{array}$ & $\begin{array}{l}0.0099 * * * \\
(0.003)\end{array}$ \\
\hline Observations & 838 & 269 \\
\hline R-squared & 0.409 & 0.470 \\
\hline
\end{tabular}


Table 5. Effects of (Non)Cognitive Skills on Annual Income by Employment Status and Company Siz Depdent Variables

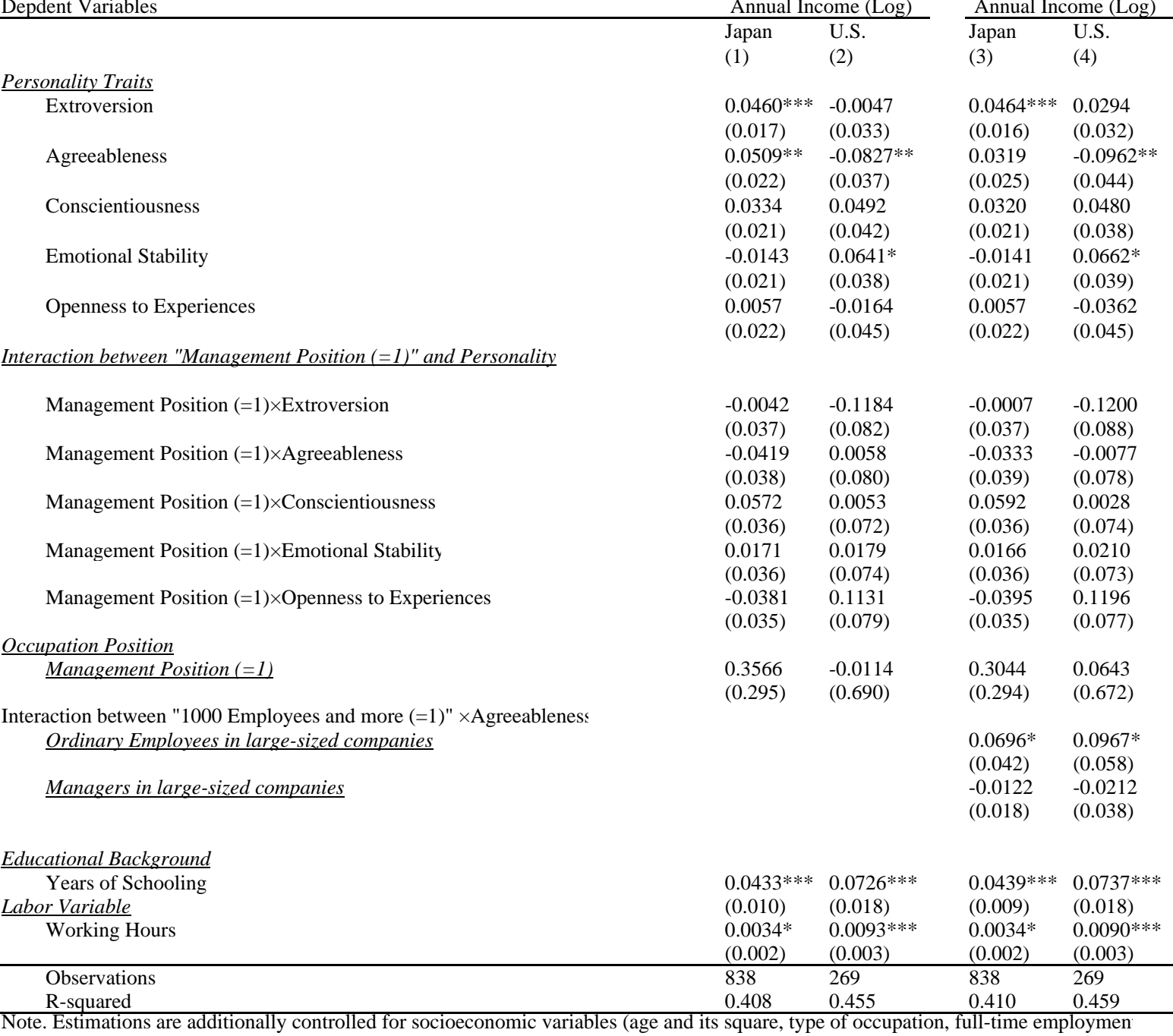

Note. Estimations are additionally controlled for socioeconomic variables (age and its square, type of occupation, full-time employmen years of employment at current workplace, and race dummies [only American samples]). Robust standard errors are in parentheses. $* * * \mathrm{p}<$ $0.01,{ }^{* *} \mathrm{p}<0.05, * \mathrm{p}<0.1$ 
Table 6. Effects of (Non)Cognitive Skills on Career Advancement

\begin{tabular}{|c|c|c|c|c|}
\hline \multirow{3}{*}{$\begin{array}{l}\text { Dependent variable } \\
\text { Model: Probit } \\
\underline{\text { Personality Traits }}\end{array}$} & \multicolumn{4}{|c|}{ Management Position (=1) } \\
\hline & \multicolumn{2}{|c|}{ Male Workers (Japan) } & \multicolumn{2}{|c|}{ Male Workers (U.S.) } \\
\hline & & & & \\
\hline Extroversion & $\begin{array}{l}0.1541 * * * \\
(0.042)\end{array}$ & $\begin{array}{l}0.1785^{* * * *} \\
(0.048)\end{array}$ & $\begin{array}{l}0.1265^{*} \\
(0.066)\end{array}$ & $\begin{array}{l}0.1165 \\
(0.086)\end{array}$ \\
\hline Agreeableness & $\begin{array}{l}0.0653 \\
(0.057)\end{array}$ & $\begin{array}{l}0.0433 \\
(0.068)\end{array}$ & $\begin{array}{l}0.0106 \\
(0.075)\end{array}$ & $\begin{array}{l}-0.0294 \\
(0.094)\end{array}$ \\
\hline Conscientiousness & $\begin{array}{l}0.0271 \\
(0.050)\end{array}$ & $\begin{array}{l}-0.0141 \\
(0.059)\end{array}$ & $\begin{array}{l}0.0369 \\
(0.090)\end{array}$ & $\begin{array}{l}0.0718 \\
(0.119)\end{array}$ \\
\hline Emotional Stability & $\begin{array}{l}0.0333 \\
(0.053)\end{array}$ & $\begin{array}{l}0.0534 \\
(0.062)\end{array}$ & $\begin{array}{l}-0.0087 \\
(0.068)\end{array}$ & $\begin{array}{l}-0.0016 \\
(0.090)\end{array}$ \\
\hline Openness to Experiences & $\begin{array}{l}-0.0431 \\
(0.050)\end{array}$ & $\begin{array}{l}-0.0797 \\
(0.058)\end{array}$ & $\begin{array}{l}-0.0096 \\
(0.084)\end{array}$ & $\begin{array}{l}0.0973 \\
(0.106)\end{array}$ \\
\hline \multicolumn{5}{|l|}{ Interaction between "1000 Employees and more $(=1)$ " and Personality } \\
\hline 1000 Employees and more $(=1) \times$ Extraversion & & $\begin{array}{l}0.0653 \\
(0.123) \\
-0.0628\end{array}$ & & $\begin{array}{l}0.0629 \\
(0.152) \\
0.0478\end{array}$ \\
\hline 1000 Employees and more $(=1) \times$ Agreeableness & & $\begin{array}{l}(0.099) \\
0.1538\end{array}$ & & $\begin{array}{l}(0.133) \\
-0.1252\end{array}$ \\
\hline 1000 Employees and more $(=1) \times$ Conscientiousness & & $\begin{array}{l}(0.114) \\
-0.0742\end{array}$ & & $\begin{array}{l}(0.174) \\
0.0294\end{array}$ \\
\hline 1000 Employees and more $(=1) \times$ Emotional Stability & & $(0.117)$ & & $(0.133)$ \\
\hline 1000 Employees and more $(=1) \times$ Openness to Experiences & & $\begin{array}{l}0.1262 \\
(0.117)\end{array}$ & & $\begin{array}{l}-0.3343^{*} \\
(0.175)\end{array}$ \\
\hline \multicolumn{5}{|l|}{ Company Size } \\
\hline 1000 Employees and more $(=1)$ & $\begin{array}{l}-0.3775^{* * *} \\
(0.112)\end{array}$ & $\begin{array}{l}-1.2990 \\
(0.842)\end{array}$ & $\begin{array}{l}-0.0768 \\
(0.187)\end{array}$ & $\begin{array}{l}1.6237 \\
(1.378)\end{array}$ \\
\hline \multicolumn{5}{|l|}{ Educational Background } \\
\hline Years of Schooling & $\begin{array}{l}0.1376^{* * *} \\
(0.023)\end{array}$ & $\begin{array}{l}0.1401^{* * *} \\
(0.023)\end{array}$ & $\begin{array}{l}0.0956^{* * *} \\
(0.033)\end{array}$ & $\begin{array}{l}0.0982^{* * *} \\
(0.033)\end{array}$ \\
\hline \multicolumn{5}{|l|}{ Labor Market Variable } \\
\hline Working hours & $\begin{array}{l}0.0076^{*} \\
(0.004)\end{array}$ & $\begin{array}{l}0.0076^{*} \\
(0.004)\end{array}$ & $\begin{array}{l}-0.0029 \\
(0.006)\end{array}$ & $\begin{array}{l}-0.0032 \\
(0.006)\end{array}$ \\
\hline Observations & 918 & 918 & 304 & 304 \\
\hline
\end{tabular}

Note. Estimations are additionally controlled for socioeconomic variables (age and its square, full-time employment, years of employment at current workplace, and race dummies [only American samples]). Robust standard errors are in parentheses. ${ }^{* * *} \mathrm{p}<0.01,{ }^{* *} \mathrm{p}<0.05,{ }^{*} \mathrm{p}<0.1$. 


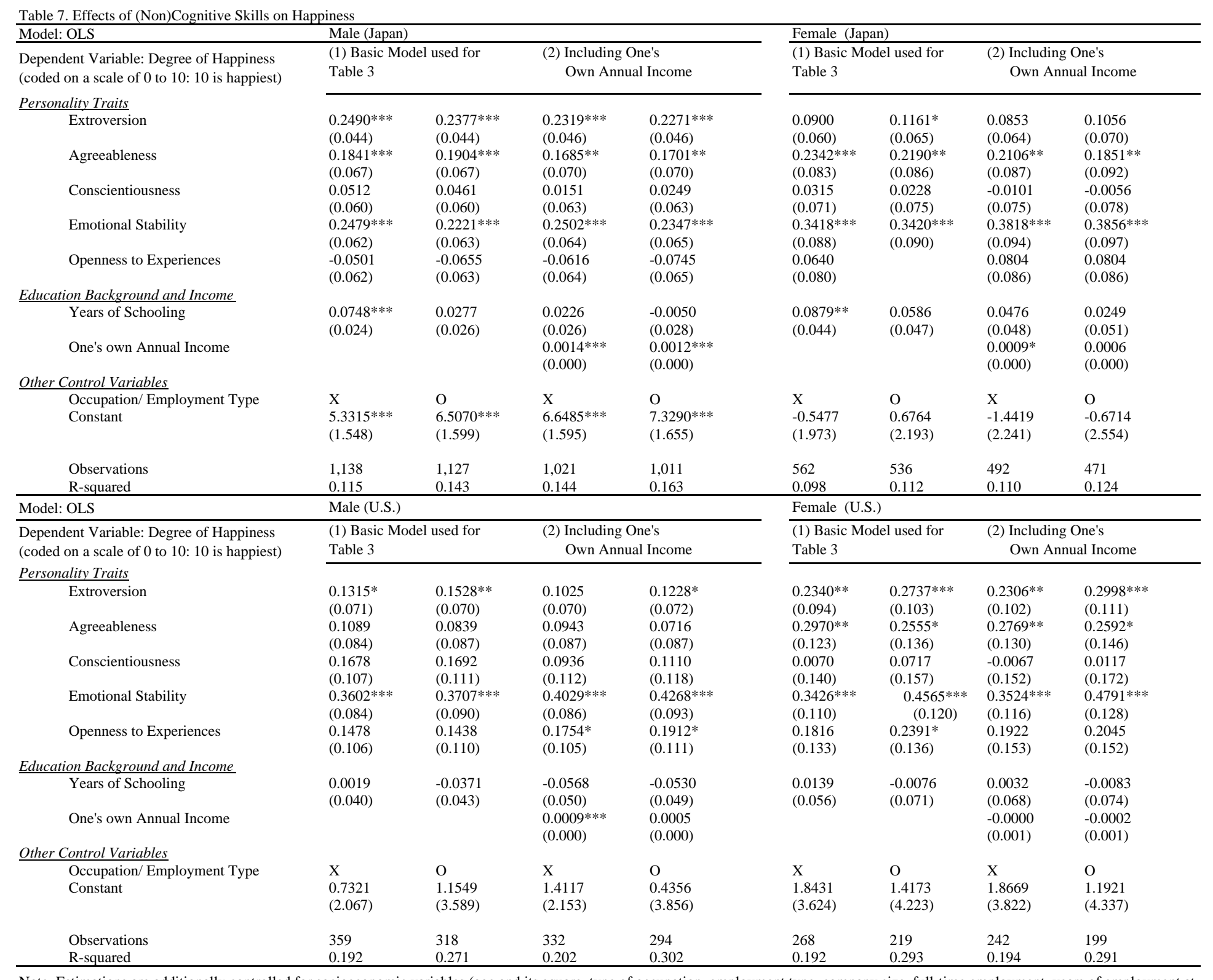

Note. Estimations are additionally controlled for socioeconomic variables (age and its square, type of occupation, employment type, company size, full-time employment, years of employment at current workplace, and race dummies [only American samples]). Robust standard errors are in parentheses. ${ }^{* * *} \mathrm{p}<0.01,{ }^{* *} \mathrm{p}<0.05,{ }^{*} \mathrm{p}<0.1$. 
Figure 1. Standardized Regression Coefficient Associated with Years of Schooling in Japan and the United States 1.2. The U.S

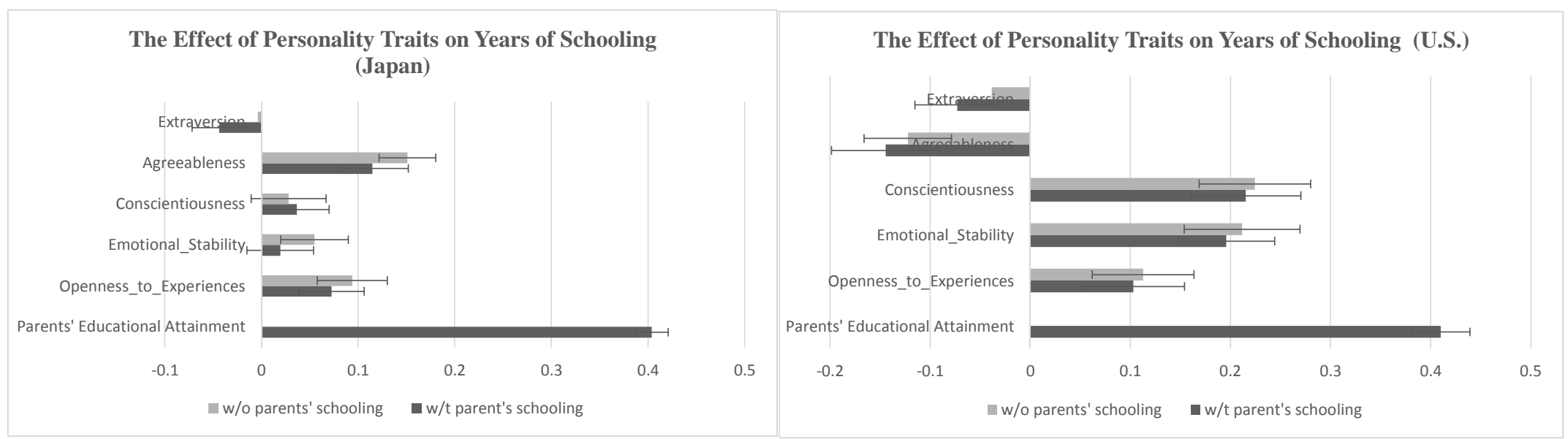

Note. Figure displays standardized regression coefficients from multivariate analysis of years of schooling completed on personality traits and parental education, controlled for age, agesquared, and gender. Darker rectangular bars are estimates with control of parental educational background, and line bars represent robust standard errors. 
Figure 2. Distribution of Noncognitive Skills
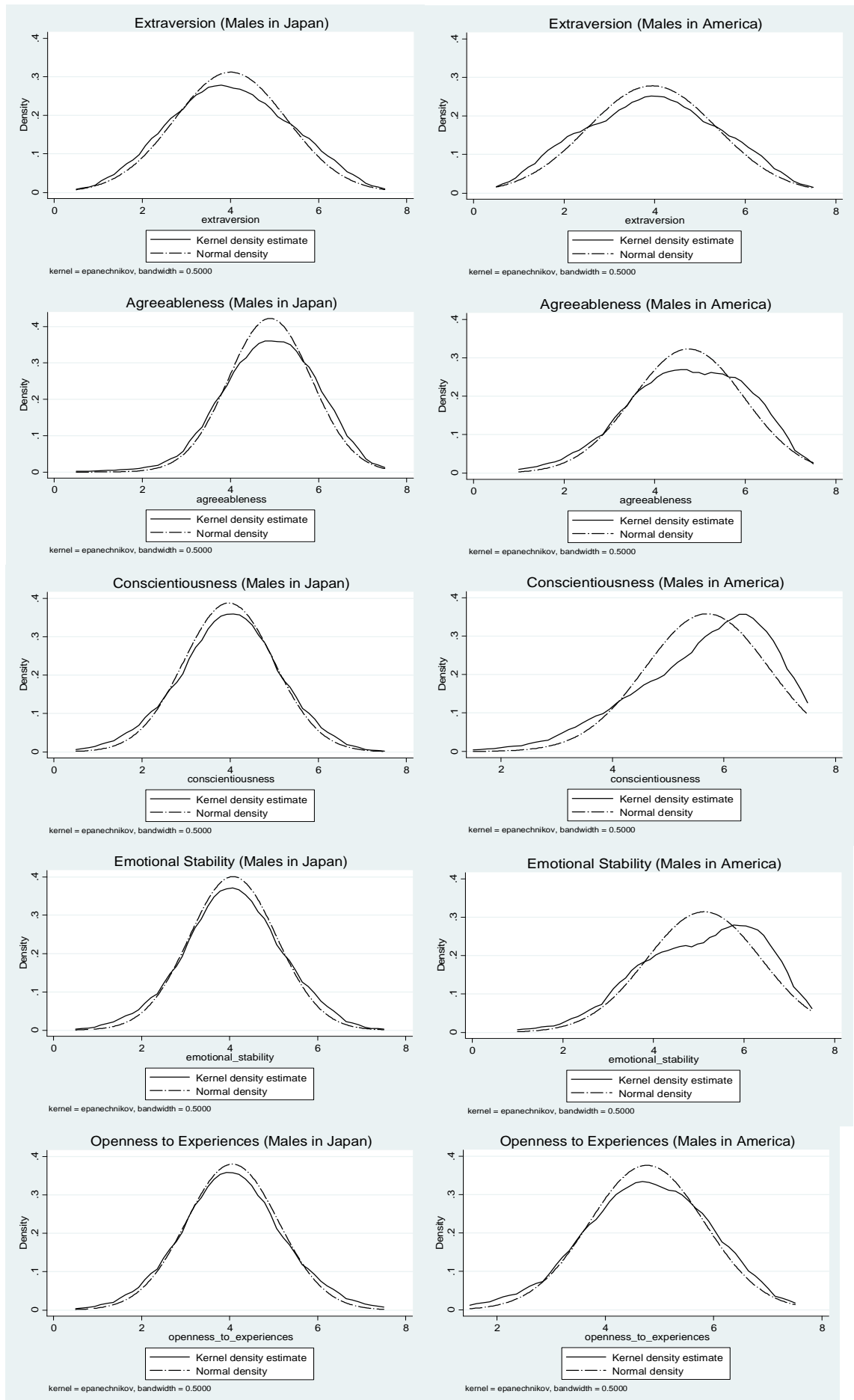

Note. Distribution of Big Five personality traits are described with samples used to analyze annual income, using a whole sample (Table 3, column 3). 